\title{
THE IDENTIFY OF CEK \& RICEK IN INTRODUCING THE YOUTUBE CHANNEL CEK \& RICEK TO THE SOCIETY
}

\author{
ABDUL RAHMAN, ANDRA REFINA MUREN, MA'MUN MUROD AL-BARASY
}

Faculty of Communication Science, Mercu Buana University

Faculty of Social and Politics Science, Muhammadiyah University Jakarta

\begin{abstract}
Cek \& Ricek is a TV program broadcasted by RCTI that delivers the news around the life of Indonesian celebrities on a daily basis. With the presence of Industrial Revolution 4.0, Cek \& Ricek that has been produced by Bintang Advis Multimedia Company has undergone a transition from print media to online digital media and even to YouTube Channel. In relation to the statement, the Industrial Revolution 4.0 has been spoken widely in the domain of manufacturing industries but the figures who have spoken it are the national ones with various background of profession; consequently, the identity of the mass media program has transitioned within its delivery to the society. Due to the content transition within the media, the researchers are compelled to review and discuss the identify of Cek \& Ricek in introducing its YouTube Channel to the society. In conducting the study, the method that has been selected is the descriptive qualitative one using the case study. Then, in gathering the necessary data, the researchers have conducted a structured interview to the respondents. The interview has been conducted online based on the agreement between the researchers and the sources whom the researchers have selected for the purpose of the study. Thus, the data sources that the researchers have used are the information from several sources who have been interviewed. The results of the study show that the YouTube Channel has been selected by Cek \& Ricek as the media of transition from print media to the digital media due to the rapid current development. With regards to the statement, there are three important aspects that influence marketing communication namely push strategy, pull strategy, and pass strategy. Within the context of the study, the three important aspects do not seem to influence the promotion for the YouTube Channel of Cek \& Ricek since the 21-year existence of the media has facilitated the introduction of the channel. Departing from the above explanation, it is apparent that the role of the YouTube Channel as a promotion media holds a very significant role in reaching out the readers of Cek \& Ricek print media, which has been terminated by the publication due to the transition into the digital media platform.
\end{abstract}

Keyword: Identity, YouTube, Content Marketing, Cek \& Ricek

\subsection{INTRODUCTION}

Cek \& Ricek is a TV program broadcasted by RCTI that delivers the news around the life of Indonesian celebrities on a daily basis. It was first broadcasted for the very first time by the TV station on August 24th, 1997. The content of the media talks about the daily life of Indonesian celebrities. The program itself has been created by Bintang Advis Multimedia. Due to the presence of Industrial Revolution 4.0 amidst the Indonesian society, Cek \& Ricek should undergo a transition from print media through the online digital media, specifically in the form of the YouTube Channel. In relation to the statement, the Industrial Revolution 4.0 has been spoken widely in the domain of manufacturing industries but the figures who have spoken it are the national ones with various backgrounds of the profession; consequently, the identity of the mass media program has transitioned within its delivery to the society. 
The nature of Cek \& Ricek content is infotainment. Back in its golden times, the production of Cek \& Ricek as a TV program was followed by the creation of its print media, which also delivers the same content. The print media itself was later known as Cek \& Ricek Tabloid. The tabloid had been concerned with the news about the celebrities and prominent public figures. Both of the TV program and the tabloid had earned the equally significant market share and this achievement had resulted in the peculiar identify of Cek \& Ricek. Unfortunately, in the present times the broadcast of the TV program and the circulation of the tabloid has been terminated.

As reported from Widuri.com (Citra, 2019), Cek \& Ricek TV Program has been broadcasted by RCTI TV Station for 21 years and this tv program has been the pioneer of the infotainment journalism in Indonesia. Unfortunately, the broadcast of Cek \& Ricek should be terminated by March 11th, 2018, due to the numerous broadcasts of children's cartoon programs. It was quite unfortunate that the development of Cek \& Ricek as part of mass media should be terminated after 21-year of existence. Similarly, the circulation of Cek \& Ricek Tabloid, which has shown its peculiarity in the front cover, should be terminated by April] 23rd, 2019. The front cover of the last edition of the tabloid was even entitled "Kami Pamit! Berpisah untuk Bertemu Kembali) \#kilk ceknricek.com." Indeed, the last edition of the tabloid has signalled the information about the transition from the print mass media into the online digital platform.

In the present days, Cek \& Ricek still has two online digital platforms namely the website Ceknricek.com and the YouTube Channel Cek \& Ricek. Both online digital platforms of Cek $\&$ Ricek are equally relatively new; in fact, the YouTube Channel of Cek \& Ricek has not been even year old. However, from the contents that have been delivered or uploaded to the channel, it is apparent that the contents have been visually rich. The characteristic of being visually rich, which is supported by the use of numerous moving pictures or videos, has marked the materials or the contents of Cek \& Ricek Media Group up to date. The level of achievement that the contents have in the form of videos that have been uploaded to the YouTube Channel can be measured based on the performance of the videos that have been uploaded. In order to measure the performance of the video and the channel completely, people can rely on YouTube Analytics. YouTube Analytics is a tool that has been designed for measuring the performance of the YouTube Channel and the YouTube Videos. This performance is based on a number of matrices that have been displayed in the form of graphics. There are many variables that can be used for the measurement based on the available matrices. For example, a video or a channel can be measured based on the number of the viewers (view), the number of the subscribers (subscriber), and the time that has been spent for watching the video or the channel (watch time). In addition, this tool can also be used for measuring the characteristics of the viewers who have watched the contents that have been uploaded and these characteristics may consist of age and gender, top countries, and device type.

Cek \& Ricek was first broadcasted with the contents that shared about popular stories around artists, celebrities, and figures altogether with other hot issues. Then, the contents that had been broadcasted in Cek \& Ricek by RCTI were also packed into the print mass media known as Cek \& Ricek Tabloid. The Cek \& Ricek Tabloid, which had been published one year after the broadcast of the TV program, also shared the similar contents with more detailed discussions over the given topics. In the present times, these contents have been packed into the contents that will be uploaded in the YouTube Channel Cek \& Ricek. The reason is that rich visual layout becomes the key influence in drawing the attention of the audience especially in the use of YouTube Channel. Indeed, YouTube Channel draws the interest of the audience especially with regards to the contents that have been related to the existence of an entity for three reasons. First, the more audience that a YouTube Channel has, 
the more the channel will be able to survive. Second, the more audience who views a YouTube Channel, the more the channel will be subscribed by the audience. Third, the more subscriptions that a YouTube Channel has, the more the channel will be responded by the advertisers and in turn the given YouTube Channel can serve as a promotional or marketing media.

In relation to the contemplation toward Industrial Revolution 4.0, there should be a strict meaning or definition about the Industrial Revolution 4.0 itself. Industry refers to the presence of radical and significant change toward the way the mankind produces goods. Nowadays, the radical and significant change has taken place in the domain of print mass media industry and such change has been marked by the transition from the physical media to the digital media (Purwadi, 2019). In this case, media digitalization refers to the process of media transformation from the analogue one into the digital one. Within the process of media digitalization, numerous physical forms from the available data are inputted into the media in the form of pictures, voices, texts, and alike. Most of these data are converted into the binary digit (binary digit " 0 " \& " 1 "). As a consequence, media production, consumption, and distribution become hugely impacted by the media digitalization. The development of the digital world has led to the transition on almost every life aspect. The resolution of the digital technology has changed the way an individual retrieves news. In the past, news should be up to date and thus news depended on the print media such as newspapers, tabloids, magazines, or electronic media such as television and radio stations. In the present, a new competitor has appeared to the surface and this competitor is the digital media or the online media. This kind of media competes with each other in delivering the most actual and in-depth information in order to draw the public attention.

Online news media are known for being able to deliver information rapidly, known as breaking news, but this characteristic is outnumbered by the characteristic of print media namely that print news media is able to deliver news completely with the depth and the sharpness that cannot be matched by the online news media. However, it is inevitable that the presence of the digital media has resulted in the decreasing sale and advertisement within the market share of the print media. Therefore, there should be a synergy between the print media and the online media and this synergy has been marked with the transition into the YouTube Channel since YouTube Channel has been very phenomenal as promotional and marketing media. YouTube Channel is very easy to create and the materials for the YouTube Channel contents are also easily attained and can also be uploaded at anytime by the owner of the channel (Sendari, 2020). In other words, the owner of a YouTube Channel holds the sole freedom in defining the contents for the channel. This nature explains why nowadays the number of YouTube Channel has developed rapidly among individuals, communities, and business groups under multiple names. So, YouTube Channel has the power to deliver the expectation of not only many people but also many companies and corporations, including Cek \& Ricek. It is this spirit that has underlaid the establishment of Cek \& Ricek TV. On the top of it, YouTube Channel can also serve as a significant promotional and marketing media under certain number of subscribers. With this nature, it is no wonder that creating YouTube Channel has been considered profitable lately.

Departing from the above explanation, through the study the researchers would like to focus on the strategies that have been implemented by the administrators of Cek \& Ricek YouTube Channel in order to gain the popularity within the society since several videos have been uploaded into the channel. At the same time, the researchers would also like to uncover how far the marketing theories, especially Push Strategy Marketing, Pull Strategy Marketing, and Pass Marketing Strategy, have been placed by Cek \& Ricek YouTube Channel in introducing the channel into the society. 


\subsection{LITERATURE REVIEW}

\section{Theory of Communication in the Context of Industrial Marketing}

Communication is a process of delivering a message from a sender, known as communicator, to a receiver, known as communicant, both directly by means of oral manner and indirectly by means of written manner in the form of media with the objective of influencing the mind of other people, changing the attitude of other people, and persuading other people to take certain actions. Communication media consists of print media (newspapers, magazines, pamphlets, banners, and alike) and electronic media (radio stations, television stations, and Internet). As an alternative, communication can be said as a contact relation within mankind, be it among individuals and among groups. In the context of the daily life, whether it is realized or not, communication has already been part of mankind itself. Ever since the birth, mankind has been equipped with the capacity to communicate with their environment (Jaiz, 2014, pp.40-42).

In a wider term, communication process is defined not only as a process of message or news exchange but also parts of individual and communal activities with regards to the exchange of data, facts, and ideas. Therefore, the functions of communication in every social system are as follows:

1. Information refers to the collection, the storage, the processing, and the dissemination of news, data, figures, facts, and messages, be in the form of opinions and comments, that are necessary to be understood and to be reacted upon clearly toward the conditions of the surrounding environment and the other people so that appropriate decisions can be made.

2. Socialization refers to the provision of science sources that enable individuals to behave and to take action as individual and as part of society effectively in order that individuals can be active within their environment (Jaiz, 2014, p.67).

In relation to the definition of communication, the components of the elements of language communication are as follows:

\section{Source}

Source refers to the basis that has been used for delivering messages and strengthening the messages that have been delivered. These sources can be in the form of individuals, institutions, books, and alike.

\section{Communicator}

Communicator can take the form of individuals who speak and write among the groups of individuals or organizations of communication such as newspapers, television stations, movies, and alike. In delivering messages, communicator sometimes can serve as communicant and, as an alternative, communicant can also serve as communicator (Santosa, 2002, p.100).

Communication theory explains the process of message delivery by a sender to a receiver through oral and written manner both directly and indirectly. In relation to the statement, digital communication refers to the transition of message delivery and this kind of communication has widely developed due to the increasing development of the media. This situation is found, for example, in the transition from the print media, such as newspapers and tabloids, into the digital media such as YouTube Channel (Santosa, 2002, pp.68-70). According to this theory, there is a review that deals with the process that has been performed 
in order to inform, persuade, warn, and deliver the presence of products or service to the public (customers) on sale so that the products or services will be purchased and thus consumed by the public (customers).

Within this framework, marketing communication holds an important for the given role. Without communication, both customers in specific and society in general will not be able to locate the presence of certain products on the market. Thus, the definition on the target of communication will highly determine the success of the communication. Through the right definition of target, the process of communication be effective and efficient. Companies implement numerous forms of marketing communication in order to promote what they have manufactured and achieved their financial objective. Thus, the marketing activities that involve marketing activities include advertisement, salesperson, store name board, display on purchase venue, product package, direct-mail, free product, coupon, publicity, and other communication tools.

\section{Mixed Marketing Communication}

According to Kotler \& Armstrong, there are five categories of mixed marketing communication (Jonathan, 2019). These categories are as follows:

\section{Advertising}

Advertising is a communication that has been performed in order to draw the awareness, internalize information, develop attitude, or expect actions that are profitable for the advertisers. Advertising is used by communicators in order to deliver the information to the public under certain objectives.

\section{Sales Promotion}

Sales promotion is a marketing way that benefits media and non-media in order to stimulate the customer needs, increase the customer demand, or improve the product quality on sale. The efforts that can be pursued by using the sales promotion are short-term in nature.

\section{Public Relations}

Public relations refer to the way of establishing good relationship with people from multiple backgrounds in order to attain the publicity under expectation, establish good company image, and handle or deal with displeasing rumours, news, or incidents.

\section{Personal Selling}

Personal selling refers to the direct interaction that customers or customer candidates establish in order to satisfy the customer needs through the sale. In this category, companies have been in direct situation with the customer candidates in order to inform the customers about a product and persuade the customers to commit purchase decision altogether at the same time.

\section{Direct Marketing}

Direct marketing refers to the direct relationship with the customers that have been accurately targeted in order to attain response and establish long-lasting customer relationship. The examples on the use of direct marketing strategy include direct mail, direct phone call, directresponse TV program, e-mail, Internet, and alike. These examples are used in order to establish direct communication with certain customers. 
With regards to the above explanation, Kotler states that there are three types of promotion strategy that can be used. The first type is known as Push Strategy, which aims at stimulating something in providing the value of satisfaction. This strategy is usually employed by salesperson in promoting the given products until the customers commit their purchase decision. Then, the second type is known as Pull Strategy, which involves the use of certain amount of fund for the needs of advertisement and customer promotion so that demands can be created on the part of the customers. This strategy will be effective if the customers demand the products from the advertisers or directly from the producers (Chandra, 2018). Last but not the least, the third strategy is Pass Strategy, which pays attention to the attention to the implementation of the promotion strategy. In this regard, Pass Strategy serves as the foundation for describing the implementation of both Push Strategy and Pull Strategy, which have been explained previously.

The activities of implementing Pass Strategy can influence the public opinion since in these activities a company may hold a special event by inviting famous public figures. Then, the activities in the Pass Strategy include promotional activities and observation toward the reality within a certain environments prior to the selection and the decision on the promotion effort that will be implemented by the given companies. With regards to the statement, the conditions of the social environment can influence the concept of the promotional activities that will be implemented.

\subsection{METHOD}

In conducting the study, the researchers implemented the post-positivistic paradigm. As having been explained, the Post-Positivistic Paradigm refers to the school of thought that strives to improve the weakness of the Positivism Paradigm. Indeed, the Post-Positivistic Paradigm shares the opinion with the Positivistic Paradigm, which states that reality is concrete and in accordance with the governing natural law. Despite the similarity, within the study the researchers focused more on the process instead of the results; therefore, the researchers had decided to adopt the descriptive qualitative approach within the study since the researchers also performed a field study as well. Then, the object of the study was Cek \& Ricek and the method that had been implemented in conducting the study was case study. Case study is a research method that suits into the research questions deal with "how" and "why." In other words, this method will work best when a researcher has little chance to control the phenomena under investigation and the focus of the given researcher lies in the contemporary (present) phenomena within the real-life context. Furthermore, with regards to the object of the study, the respondents who had been involved in the study were namely: (1) Ilham Bintang (Founder, Owner of Cek \& Ricek); (2) Ariful Hakim (Editor in Chief of Cek \& Ricek); (3) Herman Wijaya (Editor of Cek \& Ricek); (4) Teguh O. Wijaya (Managing Editor of Cek \& Ricek); and (5) Nisa Devianti Azhar (public representative who had been aware of the presence of Cek \& Ricek, especially the Cek \& Ricek YouTube Channel). These respondents were expected to be able to uncover complete information and data that heen necessary with regards to the communication strategy of Cek \& Ricek in pursuing the transformation into media digitalization.

\subsection{RESULTS AND DISCUSSIONS}

All countries throughout the globe have been suffering from the Covid-19 Pandemics at least for the last two years and this also includes Indonesia. Due to the pandemic, the researchers had been unable to go into the fieldwork and perform an in-depth interview to all of the respondents. Not to mention, the Large-Scale Social Distancing (PSBB, Pembatasan Sosial Berskala Besar) had been forced by the local government in order to bring down the fatality rate of Covid-19, resulting in the massive restriction over activities performed outside the 
house. Under such situations, the researchers had the initiative to make a phone call with the researchers so that the discussion over the topic of the study can still be pursued. Thus, this phone call served as the replacement of the intended in-depth interview. Therefore, the researchers and the respondents made an agreement to conduct some sort of online interview. The online interview began by sending the list of the questions that the researchers have drafted to the respondents.

Within the online interview, the respondents provided their responses based on the list of questions that the researchers had sent. These responses later served as the primary data that had been gathered from the online interview. The respondents themselves were from the background that had been relevant with the study and were believed to provide information related to the problem formulations and the focus of the study. Then, in order to begin the indepth interview, first of all the researchers made a contact with Mr. Ilham Bintang, the founder and the owner of Cek \& Ricek. Mr. Ilham Bintang had recently been appointed as the Commissioner of Cek \& Ricek. The results of the interview with Mr. Ilham Bintang revealed that in 1997 Cek \& Ricek had been produced as a TV program. Back in its golden era, the TV program was broadcasted twice in a week on RCTI. As a TV program, Cek \& Ricek itself was broadcasted on August 24th, 1997, for the very first time, while the last edition of Cek \& Ricek was broadcasted on March 11th, 2018.

The success of Cek \& Ricek as a TV program was later followed by the establishment of its tabloid. On August 24th, 1998, Cek \& Ricek Tabloid was first published to the society. The tabloid was published once in a week under the price IDR 10.000,00 (ten thousand rupiahs) for a single issue and within its golden times the circulation that Cek \& Ricek had attained was 600,000 (six hundred thousand) exemplars for a single issue. Just like the TV program, Cek \& Ricek Tabloid also gained its success in both retaining the readers and attaining advertisers. Cek \& Ricek itself thus was supported by a number of production houses that deal with the production of soap operas, movie televisions, and even big screen movies through the installment of their advertisement onto the tabloid.

Furthermore, several companies such as Multivision Plus, Indika Entertainment, Starvisionplus, Sinemart, Screenplay Production, and alike had routinely benefitted Cek \& Ricek as part of their promotional media. At the beginning, these companies benefitted Cek \& Ricek as part of advertisement media for their entertainment program. However, along with the turn of the time, many companies from other domains had started to benefit Cek \& Ricek as part of their advertisement media, and these companies operated in pharmacy, drugstore, cosmetic, electricity, transportation, automotive, and even banking. Unfortunately, the golden times of Cek \& Ricek should end as the media announced its last edition on April 23rd, 2019, as the administrator of the media marked that Cek \& Ricek would focus on the media digitalization to YouTube Channel as part of their digital platform. The content of the last edition even stated that the circulation of Cek \& Ricek in the end of its golden age had been 60,000 (sixty thousand) or around $10 \%$ of the peak circulation.

Before having decided to terminate the broadcast and the circulation of Cek \& Ricek, the managerial board had prepared a transition into the media digitalization. The form of the media digitalization that had been prepared was the online media known as ceknricek.com. This digital platform had been prepared since the beginning of 2018 and the digital platform was launched on April 1st, 2018, in Motion Blue Fairmont Hotel, Senayan, Jakarta. The launching of Cek \& Ricek digital media was attended by the national figure such as Bambang Soesatyo (The Chief of the House of Representatives of the Republic of Indonesia), Zulkifli Hasan (The Chief of the People's Consultative Assembly of the Republic of Indonesia), Pramono Anung (The Secretarial Minister of the Cabinet), Budi Karya Sumadi (The Minister 
of Transportation), Rahmat Gobel, Chairul Tanjung, Hariyadi Sukamdani, Garibaldi Thohir, and others.

After the end of the launching, the digital platform of Cek \& Ricek, in the form of Cek \& Ricek TV YouTube Channel, began to be active by December 15th, 2019. Until June 5th, 2020, the YouTube Channel had been viewed for 2,635,155 times. Then, the contents that had been delivered by Cek \& Ricek YouTube Channel were entertainments or one-played episodes of different subjects such as the marriage between Zaskia Gotik and Sirajuddin (22 views), the duet of Bidadari Surga between Syakir Daulay and Adiba Khanza (1,348 views), the arrest of Dwi Sasono due to drug abuse (16 views), the charity concert of Agnez Mo and Rossa (2,688 views), Raffi Ahmad as successful YouTubers (45 views), Glenn Fredly $(59,000$ views), and the "Aisyah Istri Rosulullah" song cover performance by Nissa Sabyan (79 views). Referring to the data that had been provided by the management of Cek \& Ricek, until June 5th, 2020, the number of subscribers had been 12,200 subscribers. In June 15th, 2020, by 20:20, the Cek \& Ricek YouTube Channel had been viewed for 2,716,834 times, gaining an additional number 81,679 views.

The marketing strategy that had been implemented by Cek \& Ricek was indirectly installing advertisement within the contents through the use of the brand by Cek \& Ricek Group, including the ones in the YouTube Channel. In addition, Cek \& Ricek also used the logo on the rolling titles of Hallo Selebriti Infotainment Program that had been broadcasted by SCTV. The consistent use of the brand indirectly became a peculiar promotion for the Cek \& Ricek YouTube Channel. At the same time, the brand had also been the peculiar keyword of search for Cek \& Ricek itself.

\section{Marketing Identity of Cek \& Ricek within the Society}

In implementing the strategy of marketing identity for Cek \& Ricek, several ways should be afforded in order to be able to inform, persuade, warn, or deliver the presence of the products and services to the public (customers) (Ariful, 2021). With regards to the statement, the Editor in Chief of Cek \& Ricek states that the 21 years of existence has been more than enough to be remembered by the public and, therefore, there should not be any hard work for introducing the brand to the public. However, in terms of contents there should be more intense publication since there have been differences between the conventional media and the digital media. In addition, according to to Teguh O. Wijaya as the Managing Director of Cek \& Ricek, the implementation of marketing strategy that has been pursued by Cek \& Ricek has not changed at all since the brand has been well-known within the society. The two respondents, in this regard, have trusted the brand as the credible media and their trust has also been brought during the digitalization of Cek \& Ricek. Because of the media digitalization, nowadays it has been very easy to reach the respondents especially with the presence of WhatsApp, Instagram, Twitter, and alike.

Furthermore, Herman Wijaya as the Managing Editor of Cek \& Ricek states that the strategy of print media implementation sometimes deals with the availability of the sources to be reached by phone. Actually, the sources are always be willing to share any relevant information but he or she should be debriefed first with regards to the materials that will be discussed. In addition, the resources should be encouraged to share the detail of the information that he or she has especially if the content is highly important. These aspects should be given full attention because the main creed in journalism is to cover both sides. In order to do so, there should be confirmation from the sources. Similar principles can also be applied to interview, but interview has different technical preparation. With regards to infotainment, presenting sources face-to-face is compulsory because the materials of infotainment are more favoured by the audience since it is always difficult to gather the 
gossip from the public figures. This explains why media should hunt the figures in their house or in their event.

\section{Promotion Using YouTube in Cek \& Ricek}

Promotional activities have been pursued by numerous media elements nowadays, especially print media, television station, and online media. Promotional activities refer to those of communications that an individual or a company performs with the public in order to introduce product/service/brand/company and also to influence the mind of the public in order that the public purchase and consume the items that have been introduced. Referring to Ariful, Cek \& Ricek can be benefitted as part of promotional media especially with the presence of its YouTube Channel, which has been very popular even until to date. The population of YouTube Channel has increased along with the ease of access and the variability of content that the audience can select. However, since the contents in the Cek \& Ricek YouTube Channel have been mostly occupied by videos, so far, the YouTube Channel has been managed by the Human Resources Department of Cek \& Ricek. This situation certainly leaves a peculiar impression among the public and therefore Cek \& Ricek has a wonderful opportunity to promote the online media ceknricek.com. Although the promotion is unofficial, the content of Cek \& Ricek YouTube Channel also has discussion over that of ceknricek.com. Cek \& Ricek indeed has played an important role and that explains why the content and the brand of Cek \& Ricek will always be remembered among the viewers. In addition, the promotional activities that have been performed up to date have made the managerial board confident enough with the performance of the online digital media. As a result, the managerial board only relies on the use of the social media-based promotion since Cek \& Ricek has already had a long history of well-reputed brand within the society.

\subsection{DISCUSSIONS}

Based on the results that the researchers have gathered through the in-depth online interview with the respondents in the study, the researchers would like to analyse these results in relation to the theory that has been outlined so that the problem formulations within the study can be solved. From the explanation that has been given by the Editor in Chief of Cek \& Ricek, there are several factors that lead to the decreasing reading interest toward print media within the society. First of all, social media and online media have a faster rate in delivering the latest news of an event in relation to the print media. As a result, the public becomes more spoiled since they can access and share the latest news through the social media. In addition, there is a huge discrepancy between the performance of the print media journalists and that of online media journalist. With regards to this statement, in Cek \& Ricek the news items should be composed under the 2000 - 5000-minimum character requirements depending on the rubric since certain rubric usually consists of 2000 characters, 3000 characters, and 5000 characters.

Then, in composing the news items Cek \& Ricek also implements the principles of check and re-check. The information or the data that have been attained should be re-checked to the sources or the competent people since the information or the data should be accurate before they are being delivered into the news items. The situation is completely different with the online media. In online media, a news items should be brief, consisting of $6-7$ paragraphs, and the issues within the news items should be necessary instead of interesting. However, the principles of check and re-check are still necessary but the nature of these principles in the online media is secondary. Online news items tend to highlight actuality, informativeness, and brevity since the news online news items are adjusted to the use of the gadget. 
People tend to read quite quickly. At the same time, online media relies on news immediacy. The transition of Cek \& Ricek from the print media into the online media through YouTube Channel has been caused more by the desire to display video uploads complete with texts and narratives in relation to the news contents of the most actual entertainment or celebrities in the present time. Although Cek \& Ricek YouTube Channel has relatively been new, the number of the viewers has reached more than 2 (two) million people within the first six months after its launch. This finding already describes that the videos that have been uploaded to the YouTube Channel of Cek \& Ricek are interesting for the viewers, especially the entertainment ones and the lifestyle ones.

The contents that have been uploaded into the YouTube Channel of Cek \& Ricek are created by the managerial team of the media brand. In relation to the statement, Google Indonesia has listed 10 categories of most favourable contents by the YouTube audience in Indonesia and two of these categories fall into the possession of Cek \& Ricek YouTube Channel. The categories of the video contents that have been uploaded by the brand media, namely the entertainment videos and the lifestyle videos, have occupied the 8th Position and the 10th Position of the list respectively; both contents have been considered interesting by Indonesian people (NIstanto, 2015). Ever since the launch of Cek \& Ricek YouTube Channel, the media brand has consistently delivered the videos that contained entertainment, lifestyle, and popular information within the society. From these aspects, it is apparent that the Cek \& Ricek YouTube Channel has followed the consistent path of its predecessors, namely Cek \& Ricek TV Program and Cek \& Ricek Tabloid.

Stone defines that in order to boost the number of views or followers over the YouTube Channel, it does not only take interesting theme but also consistency, format, and potentials of being disseminated by other people. In addition, a media should also have interesting nuance that can be discussed. The nuance intended in this regard refers to: (1) what the content is; and (2) whether the focus is on the entertainment or the pop culture. In order to achieve this end, the strategy that has been pursued is consistently uploading videos in accordance with the schedule and these videos should have consistent format and identity. The structure that has been established within the format of the video production should maintained throughout the channel. Furthermore, Stones also states that the inconsistent format will throw the public into confusion and misunderstanding about the contents that have been uploaded into the YouTube Channel. Therefore, keeping the content simple while maintaining the consistent format is much more preferrable.

Azhar (2021) states that the consistency shown by Cek \& Ricek makes the viewers of the media become loyal in viewing its YouTube Channel. Furthermore, he states that the viewers loyally watch the contents of the Cek \& Ricek YouTube Channel because this channel holds discussions over entertainment such as family stories, communication among family members, family profiles, success stories, lifestyles, and even recent gossips among Indonesian celebrities. Even one of the respondents from the public representative states, "Cek \& Ricek YouTube Channel is one of my favourite programs. I always watch this channel in order to gather the latest information around the entertainment since the contents of this channel are in line with the reality."

In preparing the activation of the YouTube Channel, the managerial team of Cek \& Ricek does not make any special preparation. The reason is that the media has already had good brand great personal branding within the public since it has been well-known for 21 years. Such achievement is the main capital that the media has in creating one episode of infotainment after another. In fact, the brand of Cek \& Ricek that has been well-known by both the television audience and the tabloid readers consciously or unconsciously have encouraged and even influence the viewers to watch the Cek \& Ricek YouTube Channel. 
Apart of its interest as a promotional media, the administrator of Cek \& Ricek YouTube Channel intentionally does not install any advertisement in order to gather the popularity for the channel within the public mind. In introducing and promoting the YouTube Channel, the administrator of Cek \& Ricek have maximized the layout of the contents in terms of theme, figure, and even frame. For example, the effort to keep displaying the logo of Cek \& Ricek can be found in another digital product under the media brand namely Hallo Selebriti. In this infotainment, Cek \& Ricek still displays the logo and the rolling titles as a strategy for increasing the audience awareness toward the products under the media brand. Thus, the media brand that has been displayed by Cek \& Ricek automatically becomes the keyword for the search, resulting in great possibility to display the videos of Cek \& Ricek.

The strategy implementation by the administrator of Cek \& Ricek should aim at lifting the YouTube Channel of Cek \& Ricek itself. By putting on the logo and the rolling titles on the infotainment within the production of the media brand, the YouTube Channel of Cek \& Ricek indirectly becomes the unofficial advertisement for the products that use the brand of the media. This situation deals with the concept of advertisement with regards to a kind of information that an individual, an institution, a foundation, or a company disseminates and the information itself is usually an interesting message about products, services, or brands that have been intended for the public. The objective of the advertisement, in this case, is to encourage the public to be interested in using the products or the services that have been offered in the YouTube Channel of Cek \& Ricek.

\subsection{CONCLUSIONS}

Based on the results of the study and also the discussions within the study with regards to the identify of Cek \& Ricek in introducing the Cek \& Ricek YouTube Channel to the public, the researchers would like to draw several conclusions. First of all, the administrator of Cek \& Ricek has striven to turn the media into a group of media conglomeration in order to maintain its existence within a single brand namely Cek \& Ricek itself. The reason is that the four platforms have been dealing with the composition and the discussion over the world of celebrities and the topics of popular news within the public. The presence of communication strategy becomes an in important factor within the administration of Cek \& Ricek, be it in the print media and in the digital media. With regards to the statement, the three marketing strategies, namely Push Strategy, Pull Strategy, and Push Strategy, have not been used by the business entity of Cek \& Ricek within its transformation from the print media into the digital media. The reason is that the 21-year existence in the form of TV program and tabloid has been more than enough to serve as a capital for gaining the public interest. The administrator of Cek \& Ricek believes that public will go along with the transition of the media since they always demand for latest information from the world of celebrites.

The main source of financial income in the digital platform of Cek \& Ricek is paid advertisement. The instalment of the advertisement aims at supporting the display of the latest content in its YouTube Channel. In other words, advertisement has been the sole source of income for the Cek \& Ricek YouTube Channel. On the contrary, the source of income for the Cek \& Ricek Tabloid does not only come from the advertorial or advertisement but also the sale of the tabloid. Each of the tabloid sale and the advertisement has contributed to the composition of Cek \& Ricek income respectively, reaching 80\% in total. Apart of these findings, the way Cek \& Ricek has introduced its YouTube Channel to the public relies on the implementation of marketing communication strategy, especially Push Strategy, Pull Strategy, and Pass Strategy by putting on the logo and the rolling titles of Cek \& Ricek on the digital product. At the same time, the management of Cek \& Ricek has put on the logo and the rolling title of the media into Hallo Selebriti Program, which is an infotainment broadcast in SCTV. 
Eventually, the logo Cek \& Ricek that has been well-known for 21 years has been turned into brand awareness. Thus, the use of the logo can be considered as a strategy for influencing the audience. Furthermore, the consistency of the contents that have been presented with regards to the life of artists, celebrities, public figures, and hot issues can encourage and even attract the audience to keep watching Cek \& Ricek YouTube Channel. The brand's popularity for 21 years serves as a marketing communication strategy that encourages, attracts, and even influences the audience to keep watching the channel.

\section{LIST OF REFERENCES}

\section{Journals}

Kusniadji, Suherman. (2017). Penggunaan personal selling dalam kegiatan komunikasi pemasaran pada era pemasaran masa kini, Jurnal Ilmu Komunikasi, Vol. 9, no. 2.

Mansur Suraya, Hapzi Ali, 2017, Impact of Customer Engagement to Reputation of the Bri SyariahIndonesia, International Journal of Economic Research Volume 14 Number 19 ISSN : 0972-9380.

Rohimah, A. (2018). Digitalisasi media pemasaran online dalam gugurnya pasar ritel konvensional, Jurnal Ilmu Komunikasi Fakultas Ilmu Sosial dan Ilmu Politik, Vol. 6, no. 2.

Sugiyanto, Dyah Rachmawati. 2015. Komodifikasi Berita Dibalik Ideologi Ekonomi Politik Media (Studi Pada Program 'Polemik' Di Radio Sindo Trijaya 104.6 Fm Jakarta). Jurnal Komunikasi, Vol. 7, No. 1, Juli 2015 (57-69).

Wibowo Hendika Dimas, dkk, ANALISIS STRATEGI PEMASARAN UNTUK MENINGKATKAN DAYA SAING UMKM (Studi pada Batik Diajeng Solo), Jurnal Administrasi Bisnis (JAB) Vol. 29 No.1 Desember 2015, administrasibisnis.studentjournal.ub.ac.id.

\section{Online Media Articles}

Gatra Sandro. 2019. Jokowi-Ma'ruf Menang Pilpres 2019 Versi Quick Count 9 Lembaga. Diakses di https://nasional.kompas.com/read/2019/04/18/08482481/jokowi-marufmenang-pilpres-2019-versi- quick-count-9-lembaga?,

Gabrillin Abba \& Sandro Gatra. 2019. Prabowo-Sandiaga Deklarasikan Klaim Kemenangan Pilpres. Diakses di https://nasional.kompas.com/read/2019/04/18/17454731/prabowosandiaga- deklarasikan-klaim-kemenangan-pilpres.

Prabowo Haris \& Addi M Idhom. 2019. Hasil Riset ICMI Soal Netralitas Enam Media di Pilpres 2019. Diakses di https://tirto.id/hasil-riset-icmi-soal-netralitas-enam-media-dipilpres-2019-dlE7.

Rachman Aprialdo Dylan \& Inggried Dwi Wedhaswary. 2019. Apa Alasan TKN Akhirnya Klaim Kemenangan Jokowi-Ma'ruf? Diakses di https://nasional.kompas.com/read/2019/04/19/ 21375261/apa-alasan-tkn-akhirnyaklaim-kemenangan-jokowi-maruf.

\section{Textbooks}


Abidin Zainal Yusuf, 2015, Manajemen Komunikasi (Filosofi, Konsep, dan Aplikasi) (Bandung: Pustaka Setia).

Ardianto, Elvinaro dan Lukiati Komala Erdinaya. 2005. Komunikasi Massa: Suatu Pengantar (cetakan kedua). Bandung: Simbiosa Rekatama Media.

Arifin, Anwar. 2013. Politik Pencitraan. Jakarta. Pustaka Indonesia

Cangara Hafied, 2013, Perencanaan Strategi Komunikasi,(Jakarta: PT Raja Grafindo Persada).

Efendy, Onong Uchana, 2005, Ilmu Komunikasi Teori dan Praktek,(Bandung:Remaja RosdaKarya).

Humaidi, 2010, Teori Komunikasi Dan Strategi Dakwah,(Malang: UMM Press).

Ibrahim, R. (2010). Perencanaan Pengajaran. Jakarta : Rineka Cipta

Jaiz, M. (2014). Dasar-Dasar Periklanan,(Serang, Graha Ilmu).

Kotler, P. 2005. Manajemen Pemasaran. Jakarta: Indeks Media Group.

Kotler, P. and G. Armstrong. 2004. Dasar-dasar Pemasaran, Edisi Kesembilan. (Jakarta: Penerbit Indeks).

Pace, R. Wayne, Brent D. Peterson, and M. Dallas Burnett. Techniques for effective communication. Addison-Wesley Publishing Company, 1979.

Santosa, S. (2002), Creative Advertising, (Jakarta, Kompas Gramedia).

Shefrin, H. (2007). Behavioral Corporate Finance-Decision that Create Value. Boston, America: McGrawHill/Irwin.

Van Leuween, Theo. 2008. Discourse and Practice: New Tools for Critical Discourse Analysis. New York: Oxford University Press, inc.

Widyatama Rendra 2007, Pengantar Periklanan, (Yogyakarta: Pinus).

\section{Website}

Ani, 2019, Senjakala Media Cetak, Tabloid Cek \& Ricek Setop Penerbitan, diakses di https://m.cnnindonesia.com/nasional/20190423102530-20-388736/senjakala-mediacetak-tabloid-cek-ricek-setop-penerbitan diakses pada 23 April 2019

Citra, Rosalinda Ariska, L, Nurhayati, S, Frecilia, Yessi 2017, 'Media Cetak',MediaWiki, https://widuri.raharja.info/index.php/Media_Cetak.

Nistanto. K. Reska. 2015. Video YouTube Apa Yang Disukai Indonesia?, diakses di https://tekno.kompas.com/read/2015/10/21/09050037/Video.YouTube.Apa.Yang.Dis ukai.Indonesia.

Kris Fathoni W.2015.Punya Channel YouTube? Ini Tips Agar Ramai Pengunjung!diakses di https://inet.detik.com/tips-dan-trik/d-3068095/punya-channel-youtube-ini-tips-agarramai-pengunjung 
51 | International Journal of Scientific and Management Research 04 (03) 09-25

Purwadi, didi, 2019, Kisah Ilham Bintang dan C\&R, diakses di https://m.republika.co.id/berita/kolom/wacana/pqlze7257/kisah-ilham-bintang-dan-cr

Sendari Ayu Anugra, 2020, Cara Membuat Channel YouTube untuk Pemula, Mudah dan Cepat, diakses di https://hot.liputan6.com/read/4239570/cara-membuat-channelyoutube-untuk-pemula-mudah-dan-cepat 